\title{
Physical, structural and antioxidant properties of brewer's spent grain protein
}

\section{films}

Janina L. Proañoํㅗ Pablo R. Salgado², Raúl E. Cian ${ }^{1}$ Adriana N. Mauri² and Silvina R. Drago $^{1}$

${ }^{1}$ Instituto de Tecnología de Alimentos, CONICET- Facultad de Ingeniería Química, Universidad Nacional del Litoral, $1^{\circ}$ de Mayo 3250, (3000) Santa Fe, República Argentina.

${ }^{2}$ Centro de Investigación y Desarrollo en Criotecnología de Alimentos (CIDCA, CONICET CCT La Plata - Facultad de Ciencias Exactas, UNLP-CIC) 47 y 116 S/Nº, (B1900JJ) La Plata, República Argentina.

Running title: Film forming properties of brewer's spent grain proteins

\begin{abstract}
BACKGROUND: The development of brewer's spent grain protein films with potential active packaging properties was investigated. Films were prepared by casting protein dispersions at different pHs $(2,8,11)$, plasticizers (polyethylene glycol -PEGor glycerol), and levels (0 - $\left.0.25 \mathrm{~g} \mathrm{~g}^{-1}\right)$ of PEG. Mechanical, water-barrier and solubility, optical, antioxidant (reducing power, $\mathrm{ABTS}^{\bullet+}$ and lipidic radical scavenging), and antimicrobial properties of films were determined. Also structural characteristic of films were evaluated by ATR-FTIR.
\end{abstract}

This article has been accepted for publication and undergone full peer review but has not been through the copyediting, typesetting, pagination and proofreading process which may lead to differences between this version and the Version of Record. Please cite this article as doi: $10.1002 /$ jsfa.10597 
RESULTS: Only films prepared at pH 2 and plasticized by PEG were homogeneous in appearance and could be manipulated, thus different levels of PEG were studied at this pH. Higher PEG concentrations increased water solubility, water vapor permeability and elongation at break and decreased tensile strength and elastic modulus. PEG increased $\alpha$-helix structure only when $0.10 \mathrm{~g}^{\mathrm{PEG} \mathrm{g}} \mathrm{g}^{-1}$ BSG-PC was used. This could be related with the better mechanical properties of $\mathrm{F}_{0.10}$ films (higher tensile strength, and elastic modulus) respect to the others films. Antioxidant activity depended on PEG concentration, whereas no antimicrobial properties against Bacillus cereus, Salmonella newport and Penicillium corylophylum were detected.

CONCLUSION: The formulations with 0.10 and 0.15 g PEG g $^{-1}$ BSG-PC appear to be the most promising, balancing mechanical, water-barrier properties and antioxidant capacity of these films. Moreover, BSG proteins could be a cheap alternative for the preparation of biodegradable films, capable to be used as active food packaging.

Keywords: brewer's spent grain, protein films, active film, polyethylene glycol, antioxidant properties. 


\section{Introduction}

Global beer production amounted to about 1.94 billion hectoliters in 2018. ${ }^{1}$ Beer manufacturing produces several by-products, brewers' spent grain (BSG) being the most abundant. The main application of BSG has been basically limited to animal feeding because of its high content of protein and fiber. ${ }^{2}$ It contains about $150-250 \mathrm{~g}$ $\mathrm{kg}^{-1}$ protein, 500 - $700 \mathrm{~g} \mathrm{~kg}^{-1}$ fiber as hemicellulose, cellulose, and lignin, 50 - $100 \mathrm{~g} \mathrm{~kg}^{-}$ ${ }^{1}$ fat, and 20 - $50 \mathrm{~g} \mathrm{~kg}^{-1}$ ash. $^{3}$ Due to the significant amount produced annually, the difficulty of its disposal and its low current market value, BSG can represent an interesting by-product to process and give greater added value. Its use in the preparation of protein concentrates with good functional properties is particularly promising. In this regards, it has been reported that rich protein fractions can be obtained from BSG. ${ }^{4,5}$

The ability of BSG proteins to interact strongly among their polypeptide chains could be conducive for the development of bio-based and biodegradable materials. ${ }^{6}$ As it is known, protein films stabilized by disulfide bonds are commonly more resistant and elongable, less soluble in water and have better barrier properties. ${ }^{7}$ Moreover, modifying protein structure and the interactions between protein molecules by adjusting the $\mathrm{pH}$ of the film-forming dispersion it is possible to improve film formation and its properties. $^{8}$

In general, protein-based film formulations require the addition of a plasticizing agent to reduce the film's brittleness and confer certain plastic properties. ${ }^{9}$ Among them, the most utilized are sorbitol, polyethylene glycol, and glycerol. Plasticizer molecules have the ability to position themselves within the three-dimensional protein network and 
disrupt protein-chain hydrogen bonding, thus increasing the free volume and intermolecular spacing, ${ }^{10}$ which improve film flexibility and extensibility. ${ }^{11}$ However, plasticizers also decrease the mechanical strength and barrier properties of the films. ${ }^{12}$ Thus, both the type of plasticizer and its concentration could modify films properties.

As far as we know, the film forming properties of protein products derived from brewers' spent grain has not been practically studied. Only, Lee et al. ${ }^{13}$ prepared and characterized BSG-protein-chitosan composite films. However, there is no information about films prepared only using these proteins, neither on the effects of $\mathrm{pH}$ or plasticizer type and concentration on film forming properties of BSG-proteins. The aims of this work were to examine film forming capacity of BSG-proteins under different pHs and type of plasticizers, and to study structural characteristics, physicochemical and bioactive properties of films made with different concentrations of PEG.

\section{Materials and Methods}

This section is in the Online Resource (ESM 1).

\section{Results and discussion}

\subsection{Brewer's spent grain proteins}

Protein profiles from BSG and BSG-PC were determined using SDS-PAGE with a reducing agent ( $\beta$-mercaptoethanol). The BSG proteins (Fig. 1B) presented components higher than $90 \mathrm{kDa}$ molecular weight (no clear protein bands), bands between 89-61 $\mathrm{kDa}$ and between 43-29 $\mathrm{kDa}$ corresponding to $\mathrm{D}$, C, and B hordeins, respectively of barley (Fig. 1B). Celus et al. ${ }^{14}$ reported that BSG had D hordeins (greater than $94 \mathrm{kDa}$ ), C hordeins (between 80 and $55 \mathrm{kDa}$ ), B hordeins (between 35 and $50 \mathrm{kDa}$ ), and 
albumins and globulins (smaller than $20 \mathrm{kDa}$ ). Yalcin and Celik ${ }^{15}$ reported different hordeins fractions for barley flour: D hordeins (greater than $66 \mathrm{kDa}$ ), C hordeins (66 $45 \mathrm{kDa}$ ), B hordeins (45 - $29 \mathrm{kDa}$ ), and albumins and globulins (smaller than $29 \mathrm{kDa}$ ). During malting, barley proteins are in part degraded to amino acids and small peptides by a range of proteolytic enzymes and also are extracted in sweet wort. ${ }^{16}$ Thus, proteins remained in BSG are insoluble and non-water extractable. Only polypeptides of 47.5 kDa and 27.7 kDa were present in BSG-PC (Fig. 1C). Moreover, FPLC (Fig 1D) showed fractions of $3000 \mathrm{Da}$ and $108 \mathrm{Da}$ corresponding to oligopeptides and free amino acids obtained during alkaline extraction. In this regard, Niemi et al. ${ }^{17}$ reported that proteins solubilized from BSG by alkaline $\mathrm{pH}$ (9.5) presented bands lower than $10 \mathrm{kDa}$ in a SDS-PAGE.

Regarding protein solubility, BSG-PC had lower solubility at acidic (pH 2: $390.1 \pm 9.3$ $\mathrm{g} \mathrm{kg}^{-1}$; $\mathrm{pH}$ 4: $\left.381.4 \pm 7.3 \mathrm{~g} \mathrm{~kg}^{-1}\right)$ than at neutral $\left(\mathrm{pH} 6: 427.7 \pm 17.0 \mathrm{~g} \mathrm{~kg}^{-1}\right.$ ) or alkaline pH (pH 8: $515.5 \pm 18.9 \mathrm{~g} \mathrm{~kg}^{-1}$; pH 10: $\left.517.5 \pm 13.6 \mathrm{~g} \mathrm{~kg}^{-1}\right)$.

On the other hand, isoelectric point was at 2.92. This value was lower than 3.3 and 3.8 reported by Arauzo et al. ${ }^{18}$ and Connolly et al. ${ }^{19}$ for BSG proteins, respectively.

Amino acid profile is showed in Table 1. It is showed that large hydrophobic and small neutral side chain amino acids account $59.6 \%$ of amino acids. Moreover, BSG-PC is rich in S-containing amino acids, which could be involved in protein-protein interactions.

\subsection{Film forming conditions}


Taking into account that there are no studies reported in the scientific literature of films produced with BSG protein concentrates, a rapid screening was initially carried out to evaluate the conditions in which these proteins can form films. Only Lee et al. ${ }^{13}$ prepared films with BSG proteins, but they filtered the film forming dispersions to prepare composite films with chitosan using glycerol as plasticizer. Thus, these films were very different than those studied in this work.

It has been reported that some peptides of low molecular weight or compounds such as polyphenols could plasticize protein matrices..$^{20,21}$ Thus, considering that some components of low molecular weight in the concentrate could exercise as plasticizers, an attempt was made to obtain, in the first instance, films without plasticizers. Films prepared with BSG-PC at pH 8.0 and 11.0 were not homogeneous in appearance and could not be demolded. However, films prepared at $\mathrm{pH} 2$ were homogeneous in appearance, without visible pores or cracks brittle areas or bubbles. However, they were not easy to detach from the surface on which they were formed. Mauri and Añón ${ }^{22}$ studied the effect of $\mathrm{pH}$ on soy protein film forming capacity. They reported that the $\mathrm{pH}$ affected the charge and the degree of denaturation of the proteins, which influenced the way in which the peptide chains interact during the formation of the films and finally the hydrophilic-hydrophobic nature of protein films. Although BSG-PC showed to have lower solubility at acidic than at alkaline $\mathrm{pH}$ suggesting a higher protein-protein interaction at this $\mathrm{pH}$, proteins could be well dispersed in the filmogenic dispersion, allowing obtaining homogeneous films. Moreover, protein-protein interactions are favored at $\mathrm{pH}$ near the pI, which could favor film formation. 
Plasticizers, generally of low molecular weight, reduce the extensive interactions among protein molecules and thus decrease the material brittleness with a consequent increase in its flexibility and handling. ${ }^{23}$ The use of two plasticizers commonly used for this purpose, with different hydrophobicity was analyzed: glycerol and PEG at three different pHs: 2, 8 and 11. Fig. 2 shows the appearance of these films. Again, only those formulated at $\mathrm{pH} 2$ were homogeneous and could be easily demolded from the support, while the rest of the studied formulations resulted in very hygroscopic films that could not be removed from the mold. Those formulated with PEG at $\mathrm{pH} 2$ seemed to be the best and the most interesting to continue being studied.

In fact, PEG is a relatively small hydrophilic molecule which can be easily compatible to the BSG-PC network. Due to its low molecular weight, PEG-400 has high polarity and solubility, which favor hydrogen bonding ability and the interaction with protein chains, ${ }^{6}$ without the higher disruption of protein-protein interactions induced by

glycerol. Theoretically, plasticizers containing more polar groups $(-\mathrm{OH})$ should behave as better plasticizers for hydrophilic polymers due to the development of more proteinplasticizer interactions within the film, mainly through hydrogen bond. ${ }^{24}$ However, molecule size, solubility, and polarity of plasticizers also affect the ability of hydrogen bonding and the effectiveness of the plasticizer. ${ }^{25,26}$

\subsection{Effect of PEG concentration on physicochemical properties of films}

The effects of different ratios of PEG to BSG-PC (0.05 to $\left.0.25 \mathrm{~g} \mathrm{~g}^{-1}\right)$ over different properties of films prepared at $\mathrm{pH} 2$ were evaluated. Also, films without PEG were prepared as a control, but the characteristic brittleness of these control films caused 
them to break when were removed from the mold, allowing only properties requiring small pieces of film were analyzed.

All films were homogeneous and thin. Properties of BSG-PC films prepared at pH 2 and different concentrations of PEG are shown in Table 2.

Moisture values were within the range of $95.4-148.1 \mathrm{~g} \mathrm{~kg}^{-1}$. It increased with PEG content and this could be related with the water-holding capacity of the plasticizer. ${ }^{27}$

The solubility in water of BSG-PC films increased from 704 to $898 \mathrm{~g} \mathrm{~kg}^{-1}$ when increasing PEG content. Generally, the addition of a plasticizer raises the solubility due to the increase of the hydrophilic groups, which increase the interaction with water, and also decrease of cross-linking between polymer chains. ${ }^{28}$

The WVP of edible films ranged from $8.49 \times 10^{-11}$ to $1.00 \times 10^{-10}\left(\mathrm{~g} \mathrm{H}_{2} \mathrm{O} \mathrm{Pa}^{-1} \cdot \mathrm{s}^{-1} \cdot \mathrm{m}^{-1}\right)$. The $\mathrm{F}_{0.05}$ and $\mathrm{F}_{0.25}$ films did not resist permeation cell (with silica inside, HRc $=0$ ). These results indicate that 0.10 and 0.20 g PEG g BSG-PC were the lower and the higher levels of plasticizer that allow obtaining handled films with good water-barrier properties, $\mathrm{F}_{0.10}$ being the film with the lower WVP value. The WVP values were significantly lower than those of 100:0 and 30:70 BSG proteins: chitosan films (2.93 \pm $0.20 \times 10^{-9}$ and $2.72 \pm 0.15 \times 10^{-9} \mathrm{~g} \mathrm{H}_{2} \mathrm{O} \mathrm{Pa}{ }^{-1} \cdot \mathrm{s}^{-1} \cdot \mathrm{m}^{-1}$, respectively) reported by Lee et al. ${ }^{13}$ using glycerol as plasticizer. Also, WVP for $\mathrm{F}_{0.10}$ was lower than those obtained for films made with other proteins and glycerol 50\% (w/w, based on protein content), like gelatin $\left(10.2 \times 10^{-10} \mathrm{~g} \mathrm{~Pa}^{-1} \mathrm{~s}^{-1} \mathrm{~m}^{-1}\right)$, soy protein isolate $\left(7.54 \times 10^{-10} \mathrm{~g} \mathrm{~Pa}^{-1} \mathrm{~s}^{-1} \mathrm{~m}^{-1}\right)$, and whey protein concentrate $\left(1.54 \times 10^{-10} \mathrm{~g} \mathrm{~Pa}^{-1} \mathrm{~s}^{-1} \mathrm{~m}^{-1}\right){ }^{29}$ The amino acid profile of BSG- 
PC (Table 1) indicated that 38\% of amino acids have large hydrophobic side chain, which can be involved in the good water-barrier properties of these films.

Water susceptibility of films, analyzed by moisture content, solubility in water and WVP, is an important characteristic of films as determined their possible future application. Solubility of edible films, for example, is essential when selecting a film to pack water-rich foods and also is a significant factor that determines biodegradability and the release of bioactive compounds. ${ }^{30}$

On the other hand, films presented thickness values within the range of $83.10-106.84$ $\mu \mathrm{m}$, a maximum value being observed for $\mathrm{F}_{0.10}$, decreasing over this ratio of PEG (Table 2).

Also, films $\mathrm{F}_{0.10}$ and $\mathrm{F}_{0.15}$ presented the higher difference of color ( $\Delta E^{*}$ values). Thus, the addition of PEG induced a change on color depending on its concentration. Color is greatly affected by several factors including plasticizer addition, thermal treatment, fabrication process, and storage conditions. ${ }^{31}$ However, for protein-based films, color is most affected by protein concentration than by film treatments. ${ }^{32}$ In this case, the amount of proteins did not change among film formulas and the ratio protein/total solids decrease from 0.57 to $0.45 \mathrm{~g}_{\text {protein }} \mathrm{g}^{-1}$ total solids when increasing PEG addition. Considering films added with PEG, there was a lineal direct relationship between thickness and $\Delta E^{*}$ values (r: 0.6800).

Regarding opacity, there was a significant difference in film opacity according to PEG concentration. There was a trend to increase opacity as PEG content increased. However, $\mathrm{F}_{0.10}$ presented the lower value according at least in part to the fact this film 
had the higher thickness. It is important to mention that films did not show transmittance from 200 to $400 \mathrm{~nm}$, thus they could be an important barrier to UV radiation. Opacity is important mainly when films are used to package fatty foods, in order to slow the oxidative degradation catalyzed by light, extending the shelf life of the products. ${ }^{33}$

Results of mechanical properties of BSG-PC films are showed in Fig.3. The F0.25 films were very hygroscopic and could not be analyzed regarding mechanical properties. It was observed that the addition of PEG at low concentrations (0.05 - $0.10 \mathrm{~g} \mathrm{~g}^{-1}$ solid) resulted in higher tensile strength (Fig. 3A) and elastic modulus values (Fig. 3B), and lower elongation at break (Fig. 3C) than films formed at higher concentrations of PEG (0.15 - $\left.0.20 \mathrm{~g} \mathrm{~g}^{-1}\right)$. Guerrero and de la $\mathrm{Caba}^{34}$ reported that increasing the amount of glycerol as plasticizing in soy protein films caused a decrease of tensile strength and an increase of elongation at break due to the fact that plasticizing reduces the interactions between protein chains, thus increasing their mobility.

Lee et al. ${ }^{13}$ reported values of $4.32 \mathrm{MPa}$ for tensile strength and $36.38 \%$ elongation for films made with BSG proteins and 40\% glycerol (w/w, BSG-PC basis), but they used only soluble proteins heat treated to prepare their films.

These mechanical properties were related with the presence of secondary protein structures present in films. Fig. 3D shows deconvoluted amide I band from ATR-FTIR spectra of $\mathrm{F}_{0}$ and $\mathrm{F}_{0.10} \mathrm{BSG}$-PC films. Table 3 shows the percentages of $\alpha$-helix, $\beta$-sheet, $\gamma$-turn and random coil calculated from the amide I band of ATR-FTIR spectra. The concentration of plasticizer affected the content of secondary structures, values ranging 
17.9 to $24.9 \%$ for $\alpha$-helix; $8.0-14.6 \%$ for $\beta$-turns, $5.4-7.0 \%$ for $\beta$-sheets, $6.9-14.85 \%$ for random coils, and 9.9-16.0\% for antiparallel $\beta$-sheets. Yun et al. ${ }^{35}$ reported that $\alpha$-helix and $\beta$-turns structures are formed through intramolecular hydrogen bonding and $\beta$-sheet structures are formed through intra/intermolecular hydrogen bonding. However, if the plasticizer successfully disrupts the hydrogen network of the protein, the secondary structure will be altered significantly. It was observed that PEG increased $\alpha$-helix rate only when $0.10 \mathrm{~g} \mathrm{~g}^{-1}$ BSG-PC $\left(\mathrm{F}_{0.10}\right)$ was used. Generally, the increase in the elongation of protein films by addition of plasticizers will be the result of increased $\alpha$-helix, $\beta$-turn or random coil structures, which are more stretchable than the extended $\beta$-sheet structure. ${ }^{36}$ This could be related with the better mechanical properties of $F_{0.10}$ films (higher tensile strength, and elastic modulus) respect to the others.

\subsection{Effect of PEG concentration on bioactive properties of films}

Fig. 4 shows antioxidant capacity evaluated through the scavenging of $\mathrm{ABTS}^{\bullet+}$ radical (TEAC), reducing power (RP) and $\beta$-carotene bleaching inhibition (BBI). These values were expressed taking into account the proteins solubilized from films.

It was observed that $\mathrm{ABTS}^{\bullet+}$ scavenging capacity depended on PEG concentration, it being higher at low levels of PEG (0.05 and $0.10 \mathrm{~g} \mathrm{~g}^{-1}$ BSG-PC) (Fig. 4A). This result can be attributed to the solubilization of antioxidant low molecular weight protein components. As mentioned before, BSG-PC had oligopeptides (3000 Da) and free amino acids (108 Da). Several studies have shown that low molecular weight protein components generally possess higher radical scavenging capacity than high molecular weight proteins or peptides. ${ }^{37,38}$ In this regard, it has been suggested that low molecular 
weight protein components would access more easily to the oxidant system and lead to high values of TEAC. ${ }^{39}$

Regarding RP, the higher capacity was observed for films with PEG concentration higher than $0.10 \mathrm{~g} \mathrm{~g}^{-1}$ (Fig. 4B). Thus, RP of films depended on PEG concentration. This can be due to solubilization of antioxidant high molecular weight protein components. Note that high PEG concentrations in films formulation increased water solubility (Table 2). Therefore, the solubilization of high molecular weight protein components was favored. In this regard, Sonklin et $a l^{40}$ reported that protein components with molecular weight higher than $10 \mathrm{kDa}$ from mungbean meal protein hydrolysates showed the greatest RP at all concentrations evaluated. Thus, the higher $\mathrm{RP}$ of $\mathrm{F}_{0.15}-\mathrm{F}_{0.25}$ films may be due to the higher solubility of active components favored by PEG.

As for RP, an increase in PEG concentration produced an increase in BBI (Fig. 4C), indicating that the high molecular weight protein components are the most active. These results are in agreement with those found by Pedroche et al. ${ }^{41}$ for Brassica carinata hydrolysates. In that work, the antioxidant effect decreased with decreasing peptide size, achieving the lowest value of BBI for peptide fractions with $500 \mathrm{Da}$.

In general, it was observed that PEG affected the mechanism by which proteins exert their antioxidant effect, probably inducing changes in protein secondary structure, affecting the accessibility of the protein or polypeptides to the radicals or the electron transfer. 
Among other bioactive properties, antimicrobial properties were investigated. Due to BSG-PC has oligopeptides (Fig 1D), antibacterial and antifungal activities could be expected, ${ }^{42}$ but results showed that both BSG-PC and films did not inhibit the growing of assayed bacterial strain and fungus. Also, gelatin films did not present antibacterial properties. However, the addition of multi-wall carbon nanotubes allowed obtaining gelatin films effective against to both gram-positive and gram-negative bacteria. ${ }^{43}$

\section{Conclusion}

The formulations $\mathrm{F}_{0.10}$ and $\mathrm{F}_{0.15}$ appear to be the most promising, balancing the plasticizer content and the properties of the films (mechanical, water-barrier and antioxidant properties). This work offers new insights into a better understanding of how properties of BSG-PC films are linked with changes in protein structure induced by PEG. Moreover, BSG proteins could be a cheap alternative for the preparation of biodegradable films since the low cost of BSG. In addition, BSG-PC films exhibited some antioxidant activity, which could be considered as an advantage for active food packaging.

\section{Acknowledgements}

The authors are thankful to PICT 2879 from ANPCyT for the financial support.

\section{Declaration of conflict of interest}

The authors declare there are no conflicts of interest.

\section{References}

1 Statistica. Worldwide Beer Production [Online]. Worldw. Beer Prod. (2019). Available: $\quad$ https://www.statista.com/statistics/270275/worldwide-beer- 
production/ [9 December 2019].

2 Hussaini SJ, Moghaddam $\mathrm{N}$ and Kermanshahi $\mathrm{H}$, The Influence of Different Levels of Brewers Spent Grain and Enzyme on Performance and Digesta Viscosity of Broiler Chicks. J Anim Vet Adv 9:2608-2612 (2010).

3 Mussatto SI, Brewer's spent grain: a valuable feedstock for industrial applications. J Sci Food Agric 94:1264-1275 (2014).

4 He Y, Kuhn DD, Arogo J, Keefe SFO, Fernández C, Wiersema BD, Jin Q, Yu D and Huang $\mathrm{H}$, Wet fractionation process to produce high protein and high fiber products from brewer 's spent grain. Food Bioprod. Process 117:266-274 (2019).

5 Ibbett R, White R, Tucker $\mathrm{G}$ and Foster $\mathrm{T}$, Hydro-mechanical processing of brewer' s spent grain as a novel route for separation of protein products with di ff erentiated techno-functional properties. Innovative Food Sci Emerg Technol 56:102184 (2019).

6 Turhan KN, Sahnaz F and Guner AA, Spectrophotometric Study of Hydrogen Bonding in Methylcellulose-based Edible Films Plasticized by Polyethylene Glycol. J Food Sci 66:59-62 (2001).

7 Salgado PR, Molina Ortiz SE, Denavi GA, Bosch MA, Añón MC and Mauri AN, Influence of protein conformation on the properties of soybean protein edible films, in Soy-based Bioplastics, ed. by Thakur VK, Thakur MK and Kessler MR. Smithers Rapra Technology, UK, pp. 75-94 (2017).

8 Kowalczyk D, Biopolymer/candelilla wax emulsion films as carriers of ascorbic 
acid - A comparative study. Food Hydrocolloids 52:543-553 (2016).

9 Hernandez-Izquierdo VM and Krochta JM, Thermoplastic Processing of Proteins for Film Formation — A Review. J Food Sci 73:30-39 (2008).

10 Vieira MGA, da Silva MGAVMA, dos Santos LO and Beppu MM, Naturalbased plasticizers and biopolymer films : A review. Eur Polym J 47:254-263 (2011).

11 Araujo-Farro C P, Podadera G, Sobral PJA and Menegalli FC, Development of films based on quinoa (Chenopodium quinoa , Willdenow) starch. Carbohydr Polym 81:839-848 (2010).

12 Karbowiak T, Debeaufort F, Champion D and Voilley A, Wetting properties at the surface of iota-carrageenan-based edible films. J Colloid Interface Sci 294:400-410 (2006).

13 Lee J, Lee J, Yang H and Song KB, Preparation and characterization of brewer's spent grain protein-chitosan composite films. J Food Sci Technol 52:7549-7555 (2015).

14 Celus I, Brijs K and Delcour JA, The effects of malting and mashing on barley protein extractability. J Cereal Sci 44:203-211 (2006).

15 Yalcin E and Celik S, Solubility properties of barley flour, protein isolates and hydrolysates. Food Chem 104:1641-1647 (2007).

16 Benkovská D, Flodrová D, Psota V, and Bobál’ová J, Vliv pivovarského procesu na profil proteinů ječmene. Kvas Prum 2011:260-265 (2011).

17 Niemi P, Martins D, Buchert J and Faulds CB, Pre-hydrolysis with carbohydrases 
facilitates the release of protein from brewer's spent grain. Bioresour Technol 136:529-534 (2013).

18 Arauzo PJ, Du L, Olszewski MP, Meza Zavala MF, Alhnidi MJ and Kruse A, Effect of protein during hydrothermal carbonization of brewer's spent grain. Bioresour Technol 293 (2019).

19 Connolly A, Piggott CO and Fitzgerald RJ, Characterisation of protein-rich isolates and antioxidative phenolic extracts from pale and black brewers ' spent grain. Int J Food Sci Tecnnology 48:1670-1681 (2013).

20 Cian RE, Salgado PR, Drago SR, González RJ and Mauri AN, Development of naturally activated edible films with antioxidant properties prepared from red seaweed Porphyra columbina biopolymers. Food Chem 146:6-14 (2014).

21 Salgado PR, Fernández GB, Drago SR and Mauri AN, Addition of bovine plasma hydrolysates improves the antioxidant properties of soybean and sun flower protein-based films. Food Hydrocolloids 25:1433-1440 (2011).

22 Mauri AN and Añón MC, Mechanical and Physical Properties of Soy Protein Films with pH-Modified Microstructures. Food Sci Technol Int 14:119-125 (2008).

23 Mauri AN, Salgado PR, Condés MC and Añón MC, Films and coatings from vegetable proteins, in Edible Films and Coatings: Fundamentals and Applications, ed. by Montero MP, Gómez-Guillén MC, López-Caballero ME and Barbosa-Cánovas GV. CRC Press Taylor \& Francis Group, USA, pp. 67-87 (2016). 
24 Yang L and Paulson AT, Mechanical and water vapour barrier properties of edible gellan films. Food Res Int 33:563-570 (2000).

25 Kowalczyk D and Baraniak B, Effects of plasticizers , pH and heating of filmforming solution on the properties of pea protein isolate films. J Food Eng 105:295-305 (2011).

26 Suderman N, Isa MIN and Sarbon NM, The effect of plasticizers on the functional properties of biodegradable gelatin-based film: A review. Food Biosci 24:111-119 (2018).

27 Jafarzadeh S, Alias AK, Ariffin F and Mahmud S, Physico-mechanical and microstructural properties of semolina flour films as influenced by different sorbitol / glycerol concentrations. Int J Food Prop 21:983-995 (2018).

28 Ghasemlou M, Khodaiyan F and Oromiehie A, Rheological and structural characterisation of film-forming solutions and biodegradable edible film made from kefiran as affected by various plasticizer types. Int J Biol Macromol 49:814-821 (2011).

29 Kaewprachu BP, Osako K, Benjakul S, Tongdeesoontorn W and Rawdkuen S, Biodegradable Protein-based Films and Their Properties: A Comparative Study. Packag Technol Sci 29:77-90 (2016).

30 Sharma L and Singh C, Sesame protein based edible films: Development and characterization. Food Hydrocolloids 61:139-147 (2016).

31 Sui C, Zhang W, Ye F, Liu X and Yu G, Preparation, physical, and mechanical properties of soy protein isolate/guar gum composite films prepared by solution 
casting. J Appl Polym Sci 43382:1-9 (2016).

32 Su J, Yuan X, Huang Z, Wang X, Lu X, Zhang L and Wang S, Physicochemical properties of soy protein isolate/carboxymethyl cellulose blend films crosslinked by Maillard reactions: Color, transparency and heat-sealing ability. Mater Sci Eng C 32:40-46 (2012).

33 Romani VP, Olsen B, Collares MP, Rodrigo J, Oliveira M, Olsen B, Collares MP, Oliveira RM and Martins VG, Improvement of Fish Protein Films Properties for Food Packaging through Glow Discharge Plasma Application. Food Hydrocolloids 87:970-976 (2018).

34 Guerrero P and Caba K De, Thermal and mechanical properties of soy protein films processed at different $\mathrm{pH}$ by compression. J Food Eng 100:261-269 (2010).

35 Yun H, Kon M, Won H, Yun J, Hwa M and Hoon K, The role of glycerol and water in flexible silk sericin film. Int J Biol Macromol 82:945-951 (2016).

36 Litvinov RI, Faizullin DA, Zuev YF and Weisel JW, The alpha-Helix to betaSheet Transition in Stretched and Compressed Hydrated Fibrin Clots. Biophys J 103:1020-1027 (2012).

37 Wang C, Tian Z, Chen L, Temelli F, Liu H and Wang Y, Functionality of Barley Proteins Extracted and Fractionated by Alkaline and Alcohol Methods. Cereal Chem 87:597-606 (2010).

38 Cian RE, Alaiz M, Vioque J and Drago SR, Enzyme proteolysis enhanced extraction of ACE inhibitory and antioxidant compounds (peptides and 
polyphenols) from Porphyra columbina residual cake. J Appl Phycol 25:11971206 (2013).

39 Dávalos A, Miguel M, Bartolomé B and López-Fandiño R, Antioxidant Activity of Peptides Derived from Egg White Proteins by Enzymatic Hydrolysis. J Food Prot 67:1939-1944 (2004).

40 Sonklin C, Laohakunjit N, Kerdchoechuen O and Ratanakhanokchai K, Volatile flavour compounds, sensory characteristics and antioxidant activities of mungbean meal protein hydrolysed by bromelain. J Food Sci Technol 55:265277 (2017)

41 Pedroche J, Yust MM, Lqari H, Megias C, Girón-Calle J, Alaiz M and Millán F, Obtaining of Brassica carinata protein hydrolysates enriched in bioactive peptides using immobilized digestive proteases. Food Res Int 40:931-938 (2007).

42 Brogden KA. Antimicrobial peptides: Pore formers or metabolic inhibitors in bacteria? Nat Rev Microbiol 3:238-250 (2005).

43 Kavoosi G, Dadfar SMM, Dadfar S MA, Ahmadi F and Niakosari M, Investigation of gelatin/multi-walled carbon nanotube nanocomposite films as packaging materials. Food Sci Nutr 2: 65-73 (2014). 


\section{Legends to Figures}

Fig. 1 SDS-PAGE electrophoresis with $\beta$-mercaptoethanol of A) Molecular mass markers; B) BSG; and C) BSG-PC; D) Protein profile of BSG-PC determined by FPLC.

Fig. 2 BSG-PC films made at pH 2, 8 and 11, using Polyethylene glycol-400 (PEG) and glycerol as plasticizers.

Fig. 3 Mechanical properties measured in tensile test: A) Tensile strength (MPa); B) Elastic modulus (MPa); C) Elongation at break (\%) of BSG-PC films prepared at pH 2 and different PEG concentrations $\left(\mathrm{F}_{0.05}, \mathrm{~F}_{0.10}, \mathrm{~F}_{0.15}\right.$, and $\left.\mathrm{F}_{0.20}\right)$. Means are shown in bars. Different letters in bars mean significant differences $(p<0.05)$ among samples. D) ATR-FTIR spectra of $F_{0}$ and $F_{0.10}$ films. $F_{0}-F_{0.20}$ indicate ratios of PEG/ BSG-PC for each film formula.

Fig. 4 Antioxidant capacity of BSG-PC films prepared at $\mathrm{pH} 2$ with different PEG concentrations ( $\mathrm{F}_{0}, \mathrm{~F}_{0.05}, \mathrm{~F}_{0.10}, \mathrm{~F}_{0.15}, \mathrm{~F}_{0.20}$, and $\left.\mathrm{F}_{0.25}\right)$ evaluated by: A) ABTS*+ assay; B) reducing power (RP); C) $\beta$-carotene bleaching inhibition assay (BBI). Different letters mean significant differences $(\mathrm{p}<0.05)$ among samples. $\mathrm{F}_{0}-\mathrm{F}_{0.25}$ indicate ratios of PEG/ BSG-PC for each film formula. 
Table 1. Amino acid profile of BSG protein concentrate

\begin{tabular}{|c|c|c|c|c|}
\hline Amino Acids & Groups & $\mathrm{g} \mathrm{kg}^{-1}$ protein & $\begin{array}{l}\mathrm{Eq} \mathrm{kg}^{-1} \\
\text { protein }\end{array}$ & $\underset{(\%)}{\operatorname{Eq} \mathbf{E q ~ t o t a l}^{-1}}$ \\
\hline Asp + Glu & Acid side chain & $165.72 \pm 0.09$ & 1.18 & 15.7 \\
\hline Lys & \multirow{3}{*}{ Basic side chain } & $63.07 \pm 0.38$ & 0.43 & \multirow{3}{*}{20.5} \\
\hline Arg & & $65.70 \pm 0.33$ & 0.38 & \\
\hline His & & $114.11 \pm 0.77$ & 0.74 & \\
\hline Met & \multirow[b]{2}{*}{$\begin{array}{l}\text { S-containing } \\
\text { side chain }\end{array}$} & $27.12 \pm 1.37$ & 0.18 & \multirow[b]{2}{*}{4.2} \\
\hline Cys & & $16.54 \pm 0.07$ & 0.14 & \\
\hline Gly & \multirow{4}{*}{$\begin{array}{l}\text { Small neutral } \\
\text { side chain }\end{array}$} & $4.45 \pm 0.10$ & 0.06 & \multirow{4}{*}{21.6} \\
\hline Thr & & $44.05 \pm 0.17$ & 0.37 & \\
\hline Ser & & $53.24 \pm 0.23$ & 0.51 & \\
\hline Ala & & $61.52 \pm 0.07$ & 0.69 & \\
\hline Pro & \multirow{6}{*}{$\begin{array}{c}\text { Large } \\
\text { hydrophobic } \\
\text { side chain }\end{array}$} & $58.24 \pm 1.75$ & 0.51 & \multirow{6}{*}{38.0} \\
\hline Tyr & & $43.75 \pm 0.28$ & 0.24 & \\
\hline Val & & $56.81 \pm 0.29$ & 0.48 & \\
\hline Ile & & $46.94 \pm 0.25$ & 0.36 & \\
\hline Leu & & $100.63 \pm 0.52$ & 0.77 & \\
\hline Phe & & $78.12 \pm 0.43$ & 0.47 & \\
\hline
\end{tabular}

Table 2. Susceptibility to water and appearance of BSG-PC films prepared at $\mathrm{pH} 2$ and different PEG concentrations. 


\begin{tabular}{|c|c|c|c|c|c|c|}
\hline \multirow{2}{*}{$\begin{array}{c}\text { Film } \\
\text { s }\end{array}$} & \multicolumn{3}{|c|}{ Water susceptibility } & \multicolumn{3}{|c|}{ Appearance } \\
\hline & $\begin{array}{c}\text { Moistur } \\
\text { e content } \\
\left(\mathrm{g} \mathrm{kg}^{-1}\right)\end{array}$ & $\begin{array}{c}\text { Water } \\
\text { Solubilit } \\
\mathbf{y} \\
\left(\mathrm{g} \mathrm{kg}^{-1}\right)\end{array}$ & $\begin{array}{c}\text { Water } \\
\text { vapor } \\
\text { permeabilit } \\
y \\
\left(\mathrm{~g} \mathrm{H}_{2} \mathrm{O} \mathrm{Pa}\right. \\
\left.{ }^{1} \mathrm{~s}^{-1} \mathrm{~m}^{-1}\right) \mathbf{x} \\
\mathbf{1 0}^{-10}\end{array}$ & $\begin{array}{l}\text { Thickness } \\
\quad(\mu \mathrm{m})\end{array}$ & $\Delta \mathbf{E}^{*}$ & $\begin{array}{c}\text { Opacity } \\
\left(\mathbf{A U} \mathbf{m m}^{-1}\right)\end{array}$ \\
\hline$F_{0}$ & $\begin{array}{c}95.6 \pm \\
3.7^{\mathrm{a}}\end{array}$ & nd & nd & $95.60 \pm 3.02^{\mathrm{d}}$ & $\begin{array}{c}62.47 \\
\pm \\
0.26^{\mathrm{a}} \\
\mathrm{b}\end{array}$ & $\begin{array}{l}11.52 \pm \\
0.24^{\mathrm{b}}\end{array}$ \\
\hline$F_{0.05}$ & $\begin{array}{l}95.4 \pm \\
2.4^{\mathrm{a}}\end{array}$ & $\begin{array}{c}704.0 \pm \\
6.7^{\mathrm{a}}\end{array}$ & nd & $83.10 \pm 3.26^{\mathrm{a}}$ & $\begin{array}{c} \pm \\
1.15^{\mathrm{a}}\end{array}$ & $12.58 \pm 0.29^{c}$ \\
\hline$F_{0.10}$ & $\begin{array}{c}97.0 \pm \\
2.0^{\mathrm{a}}\end{array}$ & $\begin{array}{c}715.1 \pm \\
21.3^{\mathrm{a}}\end{array}$ & $8.5 \pm 0.3^{\mathrm{a}}$ & $\begin{array}{c}106.84 \pm \\
2.89^{\mathrm{e}}\end{array}$ & $\begin{array}{c}66.45 \\
\pm \\
0.92^{\mathrm{c}}\end{array}$ & $9.83 \pm 0.21^{\mathrm{a}}$ \\
\hline$F_{0.15}$ & $\begin{array}{c}120.5 \pm \\
4.3^{b}\end{array}$ & $\begin{array}{c}774.7 \pm \\
18.8^{\mathrm{b}}\end{array}$ & $10.7 \pm 0.3^{\mathrm{b}}$ & $88.30 \pm 2.91^{\mathrm{c}}$ & $\begin{array}{c} \pm \\
0.64^{\mathrm{c}}\end{array}$ & $12.90 \pm 0.22^{\mathrm{cd}}$ \\
\hline$F_{0.20}$ & $\begin{array}{c}119.7 \pm \\
1.5^{b}\end{array}$ & $\begin{array}{c}885.8 \pm \\
20.1^{c}\end{array}$ & $11.6 \pm 0.3^{\mathrm{b}}$ & $85.81 \pm 2.52^{\mathrm{b}}$ & $\begin{array}{c} \pm \\
0.25^{\mathrm{b}}\end{array}$ & $13.02 \pm 0.21^{\mathrm{d}}$ \\
\hline$F_{0.25}$ & $\begin{array}{c}148.1 \pm \\
4.0^{c}\end{array}$ & $\begin{array}{c}897.8 \pm \\
11.7^{\mathrm{c}}\end{array}$ & nd & $85.57 \pm 2.28^{b}$ & $\begin{array}{c} \pm \\
0.81^{\mathrm{a}}\end{array}$ & $15.63 \pm 0.21^{\mathrm{e}}$ \\
\hline
\end{tabular}


$|-|$

Values are expressed as mean \pm standard deviation. Different letters in the same column mean significant differences between samples $(\mathrm{p}<0.05) ; \mathrm{F}_{0}-\mathrm{F}_{0.25}$ indicate $\mathrm{g}$ PEG $\mathrm{g}$ ${ }^{1}$ BSG-PC for each film formula; nd: not determined.

Table 3. Percentage of secondary structure segments of total area of amide I band (ATR-FTIR) from BSG-PC films prepared at $\mathrm{pH} 2$ and different PEG concentrations.

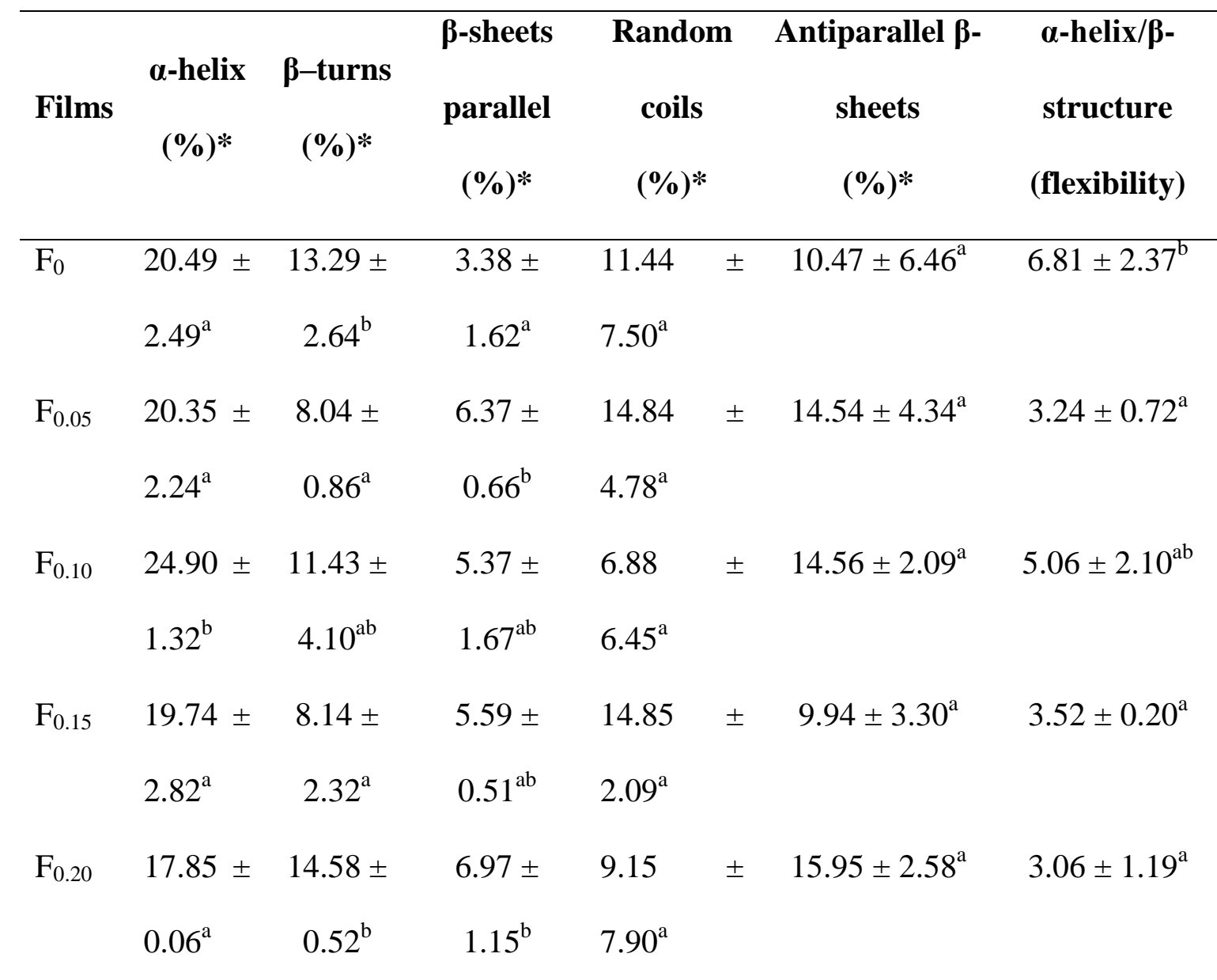

*Percentage of each protein secondary structure was calculated as the ratio of its deconvoluted peak area to the total area of the amide I band. Values are expressed as mean \pm standard deviation. Different letters in the same column mean significant 
differences between samples $(\mathrm{p}<0.05) ; \mathrm{F}_{0}-\mathrm{F}_{0.25}$ indicate $\mathrm{g}$ PEG $\mathrm{g}{ }^{-1} \mathrm{BSG}-\mathrm{PC}$ for each film formula.
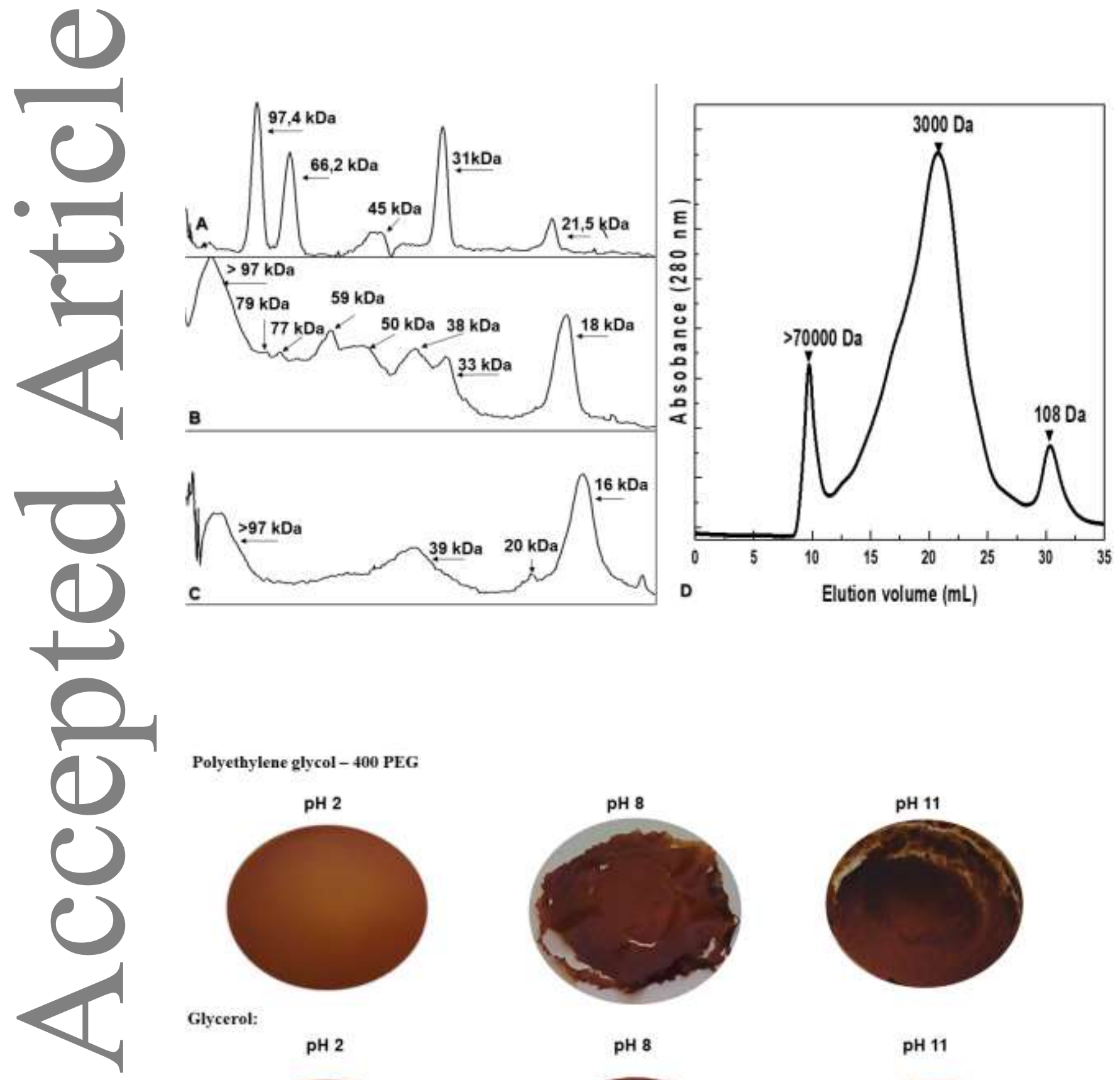

Polyethylene glycol - 400 PEG

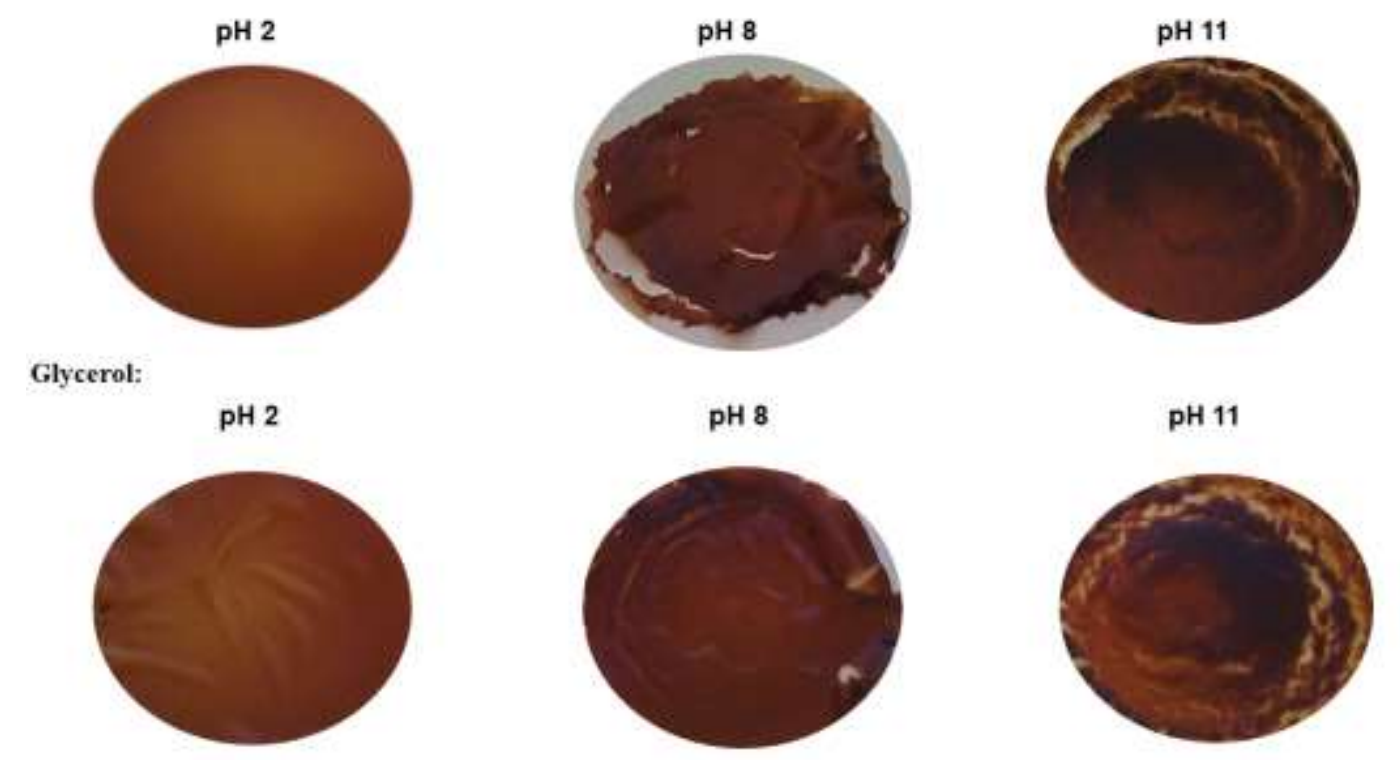




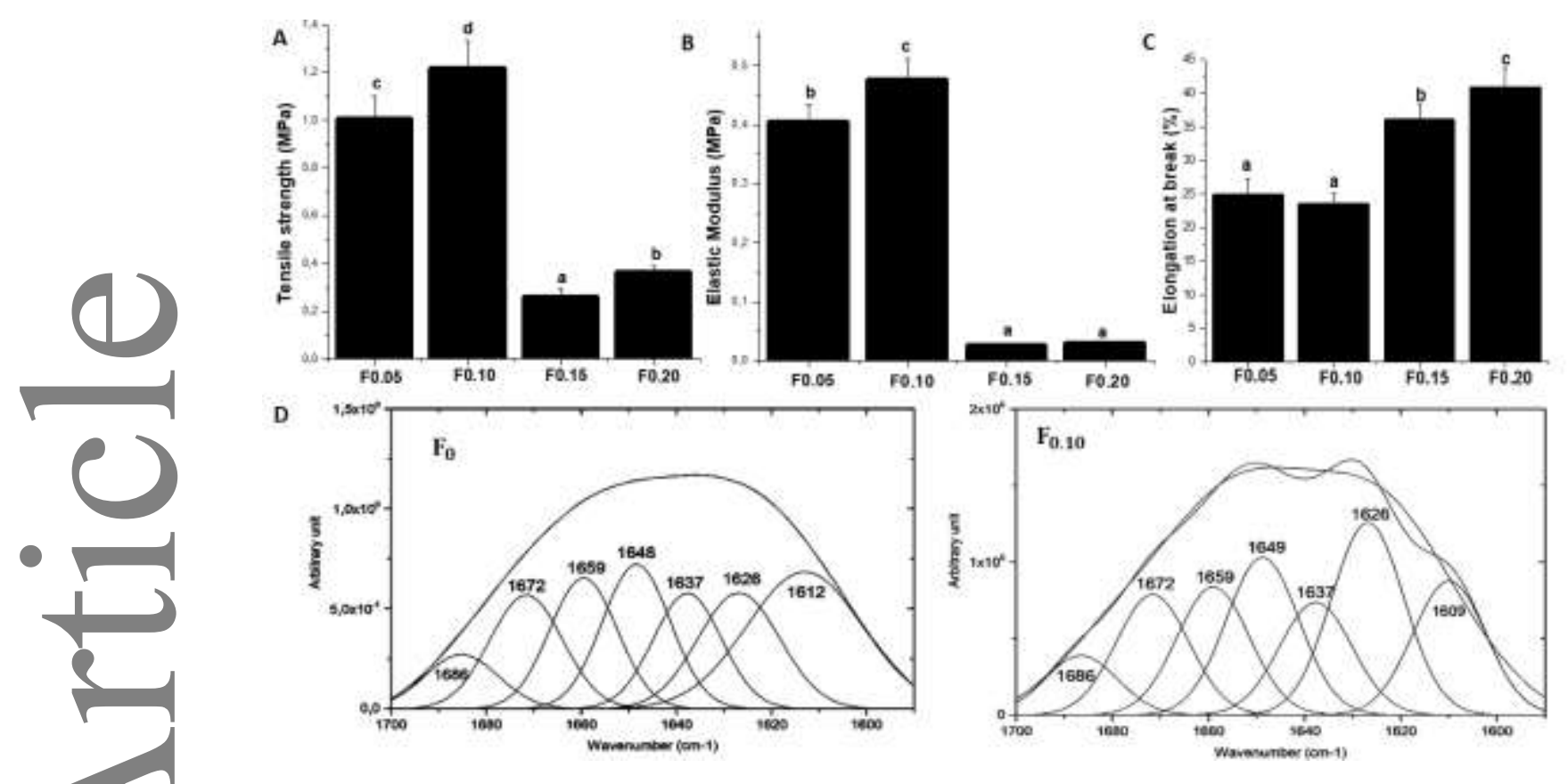

Fig. 4
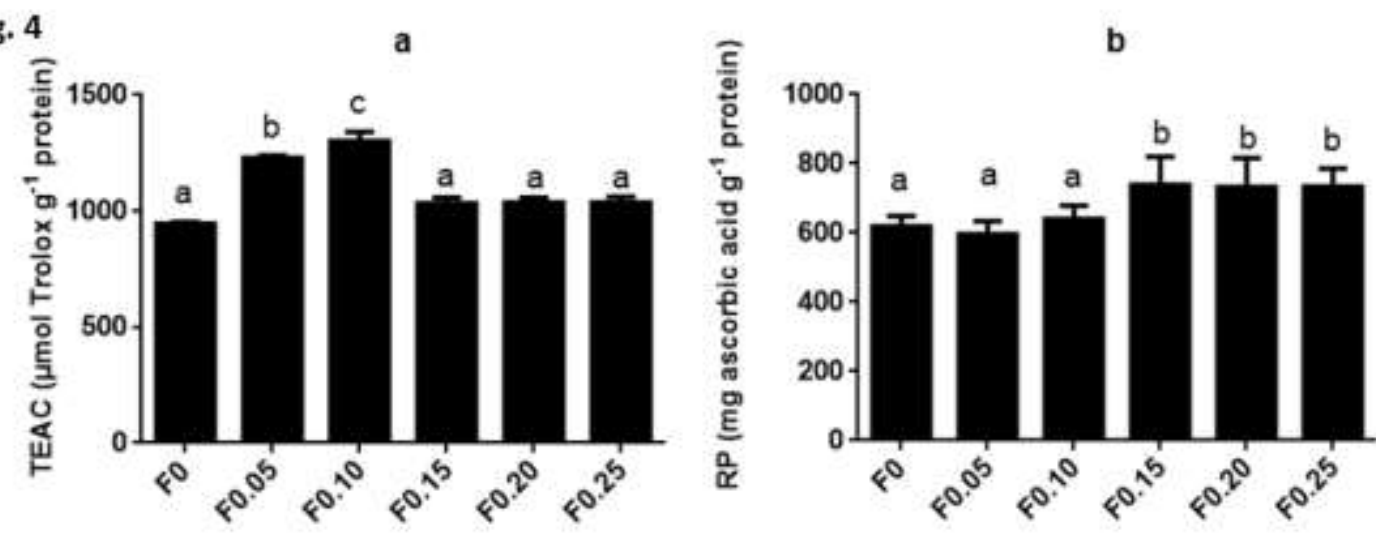

c

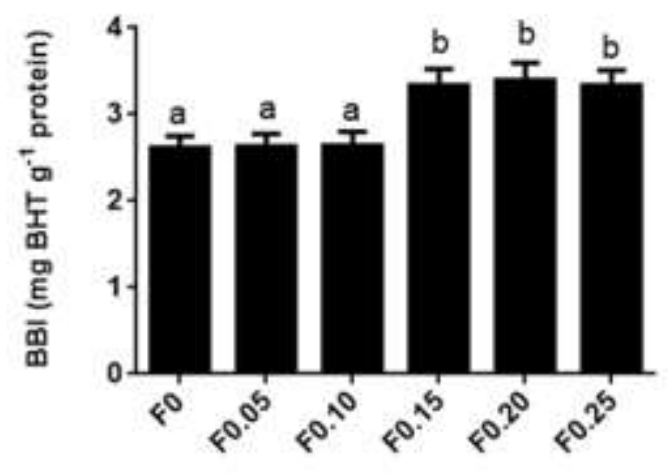

